\title{
Szlachetny nihilizm \\ a klasyczne pytanie filozofii polityki Rozróżnienie na fakty i wartości w myśli politycznej Maxa Webera
}

DOI: $10.35757 /$ CIV.2007.10.11

\section{Wprowadzenie}

Pogląd, wedle którego polityka wymaga wartości, choć marginalizowany $\mathrm{w}$ dobie panowania procedur opartych na fachowej wiedzy, wydaje się wciąż aktualny. Trudno sobie wyobrazić przedstawicieli jakiejś ludzkiej zbiorowości, którzy byliby skłonni organizować dla siebie wspólnotowy ład bez przekonania, że podobne zabiegi uczynia ich życie pod jakimś względem lepszym. Umiejętność decydowania o tym, co lepsze i gorsze wydaje się zatem zasadnicza dla polityki. Problem polega jednak na tym, na podstawie jakich kryteriów wydawany jest ów sad. Jeśli odwołamy się tu do zestawu procedur, sformułowanego przez zespół ekspertów, na przykład prawników czy ekonomistów, ryzykujemy, po pierwsze, brak legitymizacji, po drugie - wycofanie szerszych

Pawet Marczewski - doktorant w Instytucie Socjologii Uniwersytetu Warszawskiego, pracuje w Zakładzie Historii Myśli Socjologicznej. Jest członkiem redakcji „Przeglądu Politycznego”. 
grup obywateli ze sfery publicznej w sferę prywatna. O ile pierwsze niebezpieczeństwo można oddalić, przyznając wiedzy naukowej moc legitymizujaca porzadek polityczny, o tyle podobne zabiegi czynia drugi problem jeszcze bardziej istotnym.

Myślicielem, który wyraził te dylematy $z$ cała moca, był Max Weber. W eseju Nauka jako zawód i powołanie napisał: „Los naszej epoki, $z$ właściwa jej racjonalizacją i intelektualizacją, a przede wszystkim wraz $z$ dokonujacym się $\mathrm{w}$ niej odczarowaniem świata, polega na tym, że $z$ życia publicznego zniknęły ostateczne i najbardziej wysublimowane wartości. Można je odnaleźć w pozaświatowej domenie mistyki albo w braterstwie bezpośrednich stosunków łączących jednostki" ${ }^{1}$. Ostateczna konsekwencja poddania ładu politycznego naukowej racjonalizacji jest wycofanie $z$ życia publicznego w sferę kontemplacji religijnej lub też w sferę prywatna, w wąski krag rodziny i najbliższych przyjaciół. Oznacza to $\mathrm{w}$ gruncie rzeczy koniec polityki, przynajmniej w jej klasycznym kształcie, określonym przez Arystotelesa. Polityka przestaje być narzędziem rozwiązywania problemów wspólnoty, staje się problemem samym $\mathrm{w}$ sobie, który należy rozwiązać za pomocą nauki - jedynego narzędzia uznawanego za zdolne do pokonywania wszelkich trudności.

Mamy tu do czynienia $z$ istotnym paradoksem, na który wskazuje Pierre Manent, kiedy, dyskutując nad poglądami Webera w eseju Powrót filozofii politycznej, pisze: „Oddzielając fakty od wartości, siłą rzeczy zamykamy potężny potok rzeczywistości w ograniczonych formułach nauki. Nie istnieje przy tym żadna wzajemność: odtąd bowiem nie może ona odpowiedzieć na zasadnicze pytania o sens życia i świata"2. Weberowski rozdział na poddajace się racjonalnemu namysłowi fakty - przedmiot zainteresowania nauki - oraz wartości - należące do domeny „życia” i wybierane całkowicie arbitralnie albo wręcz tworzone - miał zapewnić „uczciwość

\footnotetext{
1 M. Weber: Nauka jako zawód i powołanie, w: idem: Polityka jako zawód i powołanie, oprac. Z. Krasnodebski, przekład A. Kopacki, P. Dybel, Wydawnictwo Znak, Kraków 1998, s. 138-139. 2 P. Manent: Powrót filozofii politycznej, przekład R. Mordarski, „Przegląd Polityczny” 2005, nr 69, s. 35
} 
intelektualną" naukowym przedsięwzięciom. Owa „intelektualna uczciwość" polega $z$ jednej strony na tym, by nie przyznawać nauce władzy decydowania o tym, jak powinno wyglądać dobre życie, $z$ drugiej zaś na tym, aby wartości arbitralne nie zawładnęły dociekaniami naukowymi; innymi słowy, by wartości nie przysłoniły faktów. Podział ten jest jednak niejasny, trudno bowiem sobie wyobrazić naukowca, który w swojej pracy nie dokonuje absolutnie żadnych ocen, choćby w zakresie wyboru przedmiotu swych studiów. Sam Weber przyznaje, że nauka rodzi się z pasji, $z$ niezmiernie silnego wewnętrznego przekonania o ważności własnych dociekañ ${ }^{3}$. Co więcej, podział na "fakty” i „wartości” okazuje się potężnym źródłem legitymizacji. Nauka jako jedyna zdolna jest wyrokować o faktach i jako taka staje się środkiem pozwalającym przezwyciężać niedostatki w zakresie urządzeń politycznych. W ten właśnie sposób dokonuje się proces, który Manent nazywa „rozdziałem nauki i życia”. Jego najważniejsza konsekwencja jest wycofanie $z$ życia politycznego i oddanie władzy w ręce dysponujących wiedza "fachowców”.

Lekarstwem na ten stan rzeczy wydaje się sięgnięcie po wielkie idee, zdolne mobilizować do współdziałania szerokie rzesze ludzi. Przeciwieństwem braku zaangażowania staje się stan frenetycznej wręcz aktywności publicznej, panujący w państwach totalitarnych. Lekarstwo okazuje się bardziej szkodliwe od choroby. Dla Webera polityka opierała się na ciągłej walce między sprzecznymi wartościami, wymagała ciagłych wyborów i gotowości zarówno do obrony własnych przekonań, jak i do narzucania ich innym. Totalitaryzm czy też tyrania - o różnicach między tymi dwoma pojęciami będzie jeszcze mowa - oznacza wyeliminowanie tej różnorodności. Co za tym idzie, usuwa tę cechę rzeczywistości, która sprawia, że przedsięwzięcie polityczne jest w ogóle zasadne. Gdy znika konieczność przekonywania innych do swoich racji, nie ma już miejsca na politykę. Nie pozostaje już żaden wybór, które-

${ }_{3}$ M. Weber: Nauka..., s. 117. 
go można by dokonać, żadna możliwość, za którą można by się opowiedzieć, żaden krok, który można by poczynić i następnie wziąc zań odpowiedzialność. W państwie totalitarnym jest miejsce zarówno dla przywódców, jak i dla biurokratów, nie ma jednak miejsca dla polityków.

Max Weber został nazwany przez Leo Straussa - jednego ze swoich najpoważniejszych krytyków - „szlachetnym nihilista”4. Określenie to wskazuje na paradoksalny charakter odpowiedzi autora Gospodarki $i$ społeczeństwa na klasyczne pytanie filozofii polityki, które brzmi: „kto powinien rządzić?”. Za tym na pozór prosto postawionym pytaniem kryje się wiele zagadnień, które trapiły wszystkich myślicieli - od starożytnych Greków, poprzez Machiavellego, aż po współczesnych liberałów, konserwatystów czy socjaldemokratów. Jakimi przymiotami powinien się charakteryzować idealny władca? Czy powinien nim być jeden człowiek, czy wszyscy obywatele, a może jedynie pewna ich grupa? Co sprawia, że określony podmiot można uznać za uprawniony do sprawowania władzy? Czy suwerenowi wolno używać przemocy, a jeśli tak, to w jakich okolicznościach? Odpowiedzi Webera na te pytania wyrastaja $z$ obecnego w jego myśli napięcia między ładem procedur liberalnych a silnym przywództwem, między cechujacym dobrego polityka chłodnym oglądem sytuacji a pasją właściwa jego działaniom, wreszcie między nihilizmem arbitralnych wyborów a szlachetną świadomościa konsekwencji, jakie trzeba ponieść za owe wybory.

\section{„Chłodne oko" i „gorące serce"}

Sheldon Wolin sformułował swego czasu tezę, że wielka filozofia polityczna rodzi się w odpowiedzi na kryzys, w jakim znajduje się wspólnota, do której należy dany myśliciel ${ }^{5}$. Do najważniejszych

\footnotetext{
4 L. Strauss: Prawo naturalne $w$ świetle historii, przekład T. Górski, Instytut Wydawniczy Pax, Warszawa 1969.

5 Por. S. Wolin: Politics and Vision. Continuity and Innovation in Western Political Thought, Ruskin House, London 1960.
} 
zagadnień filozofii polityki należy kwestia porządku, ładu. Gdy ów ład znajduje się w niebezpieczeństwie lub podlega gwałtownym przeobrażeniom, pojawia się potrzeba ponownego przemyślenia definiujących go do tej pory pojęć. Święty Augustyn piszacy Państwo Boże w czasie, gdy Rzym chylił się ku upadkowi, Niccoló Machiavelli spisujący rady dla Medyceusza w obliczu poważnego kryzysu republiki florenckiej, wreszcie Thomas Hobbes formułujacy swe koncepcje w ogarniętej szałem wojny domowej Anglii - lista mogłaby być zapewne o wiele dłuższa. Pozwolę sobie dodać do niej jeszcze jedno nazwisko.

Max Weber, urodzony w 1864 roku, był świadkiem zyskiwania przez zjednoczone Niemcy ogromnej potęgi, następnie zaś upadku mocarstwa po przegranej wojnie. Polityka była wielka pasją autora, który stworzył podwaliny współczesnej socjologii, a jego najważniejsze koncepcje polityczne rodziły się w odpowiedzi na przemiany będące udziałem niemieckiego społeczeństwa pod koniec XIX i na poczatku XX wieku. Nosza one piętno swoich czasów, stanowia osobliwa, ale i niezmiernie interesująca próbę przeformułowania zasad liberalnego ładu biurokratycznego w taki sposób, aby było w nim miejsce na „wielka politykę", by użyć sformułowania Alexisa de Tocqueville'a. Wielka, a więc realizowana na podstawie śmiałej wizji, głębokiego przekonania o słuszności własnych pomysłów, nie zaś zimnej kalkulacji. Wielka - to znaczy wyrastająca $z$ określonych wartości, którym mąż stanu jest wierny bez względu na okoliczności. O ile jednak dla Tocqueville’a istniała jedna wartość, na której podstawie można było realizować ową „wielka politykę" - była nią wolność - o tyle dla Webera istnieje wiele sprzecznych ze sobą wartości mogacych być przedmiotem wyboru polityka. Przed całkowitym utonięciem w chaosie różnych możliwości chroni go, po pierwsze, poczucie odpowiedzialności za raz podjęta decyzję $\mathrm{w}$ kwestii własnych przekonań. Po drugie - specyficzny pragmatyzm czy też inaczej, wedle słów samego Webera, „chłodne oko”, czyli umiejętność dokonania trzeźwej oceny sytuacji. Po trzecie wreszcie - konieczność liczenia się z logi- 
ka aparatu biurokratycznego, którego istnienie jest nieodzowne we współczesnych państwach i nowoczesnych, wielce zróżnicowanych społeczeństwach. Można zatem stwierdzić, że postulujacc powrót do „wielkiej polityki”, buduje Weber jednocześnie system swoistych checks and balances majacych ustrzec politykę przed ześlizgnięciem się w całkowitą dowolność.

O poczuciu odpowiedzialności, które powinno cechować każdego polityka, będzie szerzej mowa w części zatytułowanej Odpowiedzialność $w$ polityce, zaś problemem równoważenia interesów biurokratycznego aparatu szerzej zajmę się w części Polityka a przemoc. Rozważmy zatem w sposób nieco bardziej szczegółowy swoista dychotomię między tym, co autor szkicu Polityka jako zawód i powołanie nazywa "chłodnym okiem" a tym, co rozumie pod pojęciem „namiętność”.

Weber pisze nieco aforystycznie: „Polityka jest jak żmudne wiercenie $\mathrm{w}$ twardych deskach, a do tego potrzeba jednocześnie

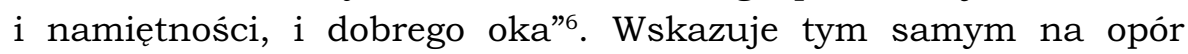
politycznej materii, na trudność, $z$ jaka tkanka życia zbiorowego poddaje się przeobrażeniom. Namiętność chroni przed zniechęceniem i nie pozwala odejść od raz powziętego planu, chłodne oko zaś pozwala nie stracić kontaktu z rzeczywistością w obliczu niepowodzeń. Obie te cechy odsyłaja na nowo do podziału na fakty i wartości. Kiedy Weber powiada, że „[...] politykę uprawia się za pomoca głowy, ale $z$ pewnościa nie tylko głowy"7, ma na myśli to, iż jedynie połączenie trzeźwego osądu $z$ silnymi przekonaniami wewnętrznymi pozwala ogarnać pełnię nowoczesnego doświadczenia, w którym zasadzające się na wartościach cele są przedmiotem arbitralnego wyboru, fakty zaś poddaja się racjonalnemu namysłowi. Pozostaje przy tym kwestia sporna, czy autor Gospodarki $i$ społeczeństwa zgłasza ów rozdział jako pewnego rodzaju postulat, punkt dojścia, jak twierdza niektórzy autorzy ${ }^{8}$. Za tym punk-

\footnotetext{
6 M. Weber: Polityka..., s. 110.

7 Ibidem, s. 108

8 Por. np. A. MacIntyre: Dziedzictwo cnoty, przekad A. Chmielewski, Wydawnictwo Naukowe PWN, Warszawa 1994.
} 
tem widzenia zdaje się świadczyć to, iż Weber traktuje oddzielenie faktów od wartości jako gwarancję „intelektualnej uczciwości”" Można jednak interpretować przemyślenia Webera jako opis stanu faktycznego, próbę ujęcia pewnej specyficznej formacji intelektualnej i społecznej, jaką w określonym momencie historii wytworzyły społeczeństwa zachodnie. Na rzecz tej interpretacji przemawiaja teksty, w których Weber opisuje postęp racjonalizacji w kulturze, nauce $\mathrm{i}$ instytucjach Zachodu jako pewien długofalowy proces oraz stara się wyjaśnić jego przyczyny ${ }^{10}$.

W tekście publicystycznym zatytułowanym $W$ sprawie „winy za wojne”, opublikowanym we „Frankfurter Zeitung” 17 stycznia 1919 roku, zaledwie cztery dni przed słynnym odczytem będącym podstawa szkicu Polityka jako zawód i powołanie, Max Weber pisał: „Przeżyliśmy w Niemczech dwa miesiące, w czasie których nasze postępowanie wobec zagranicy było tak żałosne, jak nigdy jeszcze dotąd w niemieckiej historii. Uwage świata przykuli literaci różnego autoramentu, którzy rozpamiętując poczucie "winy za wojnę" zaspokajali potrzeby swych dusz, załamanych przez wojenne okropności bądź też cechujących się ekstatycznymi skłonnościami. Taka klęska musiała być przecież skutkiem "winy" - tylko wówczas daje się ona pogodzić $z$ "porządkiem świata", jeśli jest do przyjęcia dla wszystkich tych słabych, nie umiejących stawić czoła rzeczywistości charakterów”"1. Przegrana wojna staje się tu próba "chłodnego oka", to zaś, jak zachowaja się niemieccy politycy w czasie konferencji w Wersalu będzie miarą ich zdolności do trzeźwej oceny sytuacji. Zdaniem Webera szukanie winy w narodzie, w poszczególnych częściach organizmu państwowego, jak armia czy rzą, jest przejawem politycznej niedojrzałości. Może ono być wywołane „załamaniem duszy przez wojenne okropieństwa” albo też „skłonnościami ekstatycznymi”. Ten drugi przypadek jest o wiele

\footnotetext{
9 M. Weber: Nauka..., s. 129.

${ }^{10}$ Por. np. M. Weber: Osobliwości kultury zachodniej, w: idem: Szkice z socjologii religii, oprac. St. Kozyr-Kowalski, przekład J. Prokopiuk, H. Wandowski, Książka i Wiedza, Warszawa 1984.

${ }^{11}$ M. Weber: W sprawie „winy za wojne”, w: idem: Polityka..., s. 245.
} 
bardziej niebezpieczny, ponieważ rzeczowy namysł nad sytuacja trwale ustępuje tutaj miejsca „jałowemu podnieceniu” (określenie użyte za Georgiem Simmlem w szkicu Polityka jako zawód i powołanie). Weber zaznacza przy tym, że nie należy mylić podniecenia $z$ namiętnościa, prawdziwa pasja niezbędna do uprawiania polityki. Owo jałowe uczucie - jałowe, gdyż nie płynące $z$ dokonanego świadomie wyboru drogi postępowania i nie pociagajace za soba żadnej odpowiedzialności - zwiąane jest $z$ tęsknota za starym porządkiem, ustalonym ładem, w którym nie ma miejsca na chaos konkurujących ze sobą wartości. Sformułowanie „porządek świata” zostaje $\mathrm{w}$ artykule ujęte $\mathrm{w}$ nawias - Weber pokazuje tym samym, że w gruncie rzeczy nie ma żadnego porządku poza tym, jaki sami nadajemy światu, opowiadając się za określonymi celami, dokonując wyborów i ponosząc ich konsekwencje. Dopiero zaakceptowawszy ten świat permanentnych, niemożliwych do pogodzenia sprzeczności, możemy zyskać wpływ na sytuację, możemy zaczać kształtować porządek polityczny zgodnie $z$ naszymi możliwościami i potrzebami zamiast pozwalać, by nam go narzucano. Autor Gospodarki i społeczeństwa staje się w tej kwestii uczniem Nietzschego, choć interpretuje go na własny sposób i stara się wyciagnaćc $z$ jego pism praktyczne wnioski.

W szkicu Polityka jako zawód i powołanie znajdziemy silne echa „wersalskiej lekcji”. Czytamy tam: „Zamiast, lamentując jak stare baby, szukać po wojnie "winnego" (bo przecież wojnę zrodziła struktura społeczeństwa), trzeba po męsku i cierpko powiedzieć wrogowi: "przegraliśmy wojnę, wy zwyciężyliście». To już jest za nami; teraz pozwólcie, że pomówimy o tym, jakie konsekwencje należy wyciągnąć zgodnie $z$ rzeczowymi interesami, o które toczyła się gra, oraz - co najważniejsze - w związku $z$ odpowiedzialnościa wobec przyszłości, odpowiedzialnością, która ciąży przede wszystkim na zwycięzcy" ${ }^{2}$. Wygrywając wojnę, kładziemy sobie na barki ogromny ciężar nadania światu nowego porządku, ukształtowania

\footnotetext{
${ }^{12}$ M. Weber: Polityka..., s. 99.
} 
go zgodnie $z$ własna wola i przekonaniami. Konferencja w Wersalu jest zatem lekcja nie tylko dla Niemiec, ale w dużej mierze także dla państw zwycięskich. Weber obawia się, czy staną one na wysokości zadania, czemu daje wyraz w cytowanym już artykule $W$ sprawie „winy za wojnę". Ma też poważne watpliwości, czy na podobna rzeczowość uda się zdobyć Niemcom. Pisze: „Czeka nas nie pełnia lata, lecz najpierw polarna noc, lodowato ciemna i surowa, bez względu na to, która grupa odniesie teraz zewnętrzne zwycięstwo. Albowiem: gdzie nie ma nic, tam stracił swoje prawo nie tylko cesarz, ale i proletariusz"13. Pustka, jaka pozostała po dawnym porządku, domaga się wypełnienia. Nie ma już jednak powrotu do jednej zasady organizującej ludzkie doświadczenia, do tradycji, która pozwoliłaby pogodzić ze soba rozmaite warstwy społeczne. Brak sensu odczuwaja zarówno cesarz, jak i robotnik - ale jest to jedyne, co ich łaczy w dobie nowoczesności. Jeden i drugi łatwo moga ulec w tej sytuacji „jałowemu podnieceniu”. Ustrzec ich może jedynie "chłodne oko", pozwalające trzeźwo ocenić sprzeczne interesy rozmaitych państw oraz różniących się klas czy narodów w obrębie jednego tworu państwowego. Alternatywa jest całkowite wycofanie $z$ życia publicznego w "szeroko i miłosiernie otwarte ramiona starych kościołów"14, a więc kultywowanie dawnych tradycji religijnych czy obyczajowych, które straciły już jednak moc kształtowania życia całej wspólnoty i stały się bezpowrotnie częścią sfery prywatnej.

Jedno $z$ pierwszych ważnych wystapień publicznych Maxa Webera - wykład inauguracyjny wygłoszony w 1895 roku na uniwersytecie we Fryburgu $z$ okazji objęcia katedry ekonomii politycznej - dotyczyło kwestii gospodarki rolnej oraz konfliktu rachunku ekonomicznego $z$ interesem narodowym. W jego myśli trzeźwa ocena sytuacji politycznej znajduje nieodzowne dopełnienie w namiętności, poświęceniu danej sprawie. Fryburski wykład, ale także późniejsze artykuły prasowe, przynosza bardzo ciekawy przykład podobnej

3 Ibidem, s. 110.

${ }^{14}$ M. Weber: Nauka..., s. 139. 
pasji cechujacej ludzi mających predyspozycje do uprawiania polityki. Otóż za ową pasję świadczącą o temperamencie politycznym uznaje Weber patriotyzm. W mowie wygłoszonej we Fryburgu czytamy: „Także istota problemu polityki społecznej to nie kwestia ekonomicznego położenia poddanych panowaniu, lecz raczej kwestia politycznych kwalifikacji klas panujacych i sięgajacych po panowanie"15. Prawdziwym problemem, którego symptomem jest ekspansja polskich robotników najemnych na wschodnich krańcach Niemiec, nie jest niekorzystne położenie ekonomiczne robotników niemieckich czy określone warunki gospodarcze nakazujące właścicielom ziemskim wynajmowanie pracowników gotowych zadowolić się najniższą stawką. Rzeczywista trudność leży w braku zmysłu politycznego, w braku umiłowania własnej wspólnoty politycznej. Brak patriotyzmu staje się synonimem braku dojrzałości politycznej, ten zaś oznacza utratę wolności. Kryzys zaczyna się w momencie, gdy robotnicy rolni przestaja być współgospodarzami ziemi, na której pracuja, zamiast tego otrzymując wynagrodzenie za wykonana pracę. Otwiera to drogę do masowych wędrówek „za chlebem" oraz oznacza koniec stosunków opartych na wspólnej odpowiedzialności właściciela i pracownika; zastępuje je rachunek ekonomiczny.

W późniejszym o ponad dwadzieścia lat tekście Niemcy wśród mocarstw europejskich Weber napisze: „[...] występowałem przeciw konkurencji narodowościowej według systemu tańszych rak, przeciw upośledzeniu $\mathrm{w}$ płacy za sprawą robotników zagranicznych i wystapiłem ze Związku Wszechniemieckiego, bo interes wielkich posiadaczy ziemskich $\mathrm{w}$ korzystaniu $\mathrm{z}$ tańszej, słowiańskiej siły roboczej przekładał on nad interes narodowości" ${ }^{16}$. Jednocześnie jednak podkreśla, że nie jest wrogiem Polaków, na dowód czego przytacza swój sprzeciw wobec praktyk dyskryminacji języka polskiego i germanizacji. Choć w wykładzie fryburskim pobrzmiewaja tony, które można by uznać za rasistowskie (rozpatrywanie kon-

\footnotetext{
${ }^{15}$ M. Weber: Państwo narodowe a narodowa polityka gospodarcza, w: idem: Polityka..., s. 194.

${ }^{16}$ M. Weber: Niemcy wśród mocarstw europejskich, ibidem, s. 234.
} 
fliktu na wsi niemieckiej w kategoriach starcia rasy wyżej rozwiniętej politycznie $z$ rasa stojacca na niższym stopniu rozwoju politycznego), to ton dominujacy jest inny - chodzi o powrót wielkiej polityki. Weber stara się nie dopuścić, by kalkulacje całkowicie przesłoniły polityczna wizję. "Chłodne oko” może pozwolić nam dostrzec ekonomiczne, kulturowe czy społeczne uwarunkowania istniejaccej sytuacji. W ostatecznym rachunku nie chodzi jednak o to, „jak będa się czuć ludzie przyszłości, lecz jacy będą"17. To, jacy będa ludzie przyszłości, czy przyjmą na siebie zobowiązania, jakie niesie sfera publiczna, czy też pogrą̇ą się w apatii, zniechęceniu lub zajmą po prostu liczeniem pieniędzy, decyduje się teraz, powiada Weber. Sami musimy zdecydować, czy zechcemy ocalić choć cząstkę tego, co nadaje ludzkiemu życiu sens. Kluczem do tak rozumianej polityki - tj. polityki ujmowanej jako nietzcheańska siła zdolna kształtować kondycję człowieka - jest odpowiedzialność; w konkretnym przypadku Niemiec na przełomie XIX i XX wieku oznacza to potwierdzenie wyboru dokonanego w momencie zjednoczenia.

\section{Odpowiedzialność w polityce}

Z chwila, gdy Niemcy zdecydowały się zjednoczyć i wkroczyć na arenę międzynarodowa jako mocarstwo, przyjęły na siebie jednocześnie odpowiedzialność za „wielkie polityczne kwestie mocarstwowe"18. Wraz ze wzrostem znaczenia politycznego rosna także powinności, potęga zobowiazuje - zdaje się mówić Weber. Nie chodzi jednak tylko o to, jak dane państwo kształtuje swoja politykę zagraniczna, ale przede wszystkim o to, czy jego obywatele i przywódcy dorastaja do wizji, która sami dla siebie stworzyli; czy sa wierni wartościom, za którymi się opowiedzieli. Jak czytamy w adresie fryburskim: „Musimy pojąć, że zjednoczenie Niemiec

${ }^{17}$ M. Weber: Państwo..., s. 183.

18 Ibidem, s. 194. 
było młodzieżowym wybrykiem, którego naród dopuścił się na stare lata, i jeśliby miało ono być końcem, a nie punktem wyjścia niemieckiej polityki wielkomocarstwowej, to ze względu na koszta lepiej by go było zaniechać"19. Innymi słowy, wielka polityka domaga się wielkich czynów. Jeśli raz zdecydowało się wkroczyć na kręta ścieżkę wyborów politycznych, należy nią podążać do samego końca. Dzisiejsi przywódcy polityczni, ale także szerokie rzesze ludzi biorace udział w życiu zbiorowym odpowiadaja wedle Webera „przed historia”, to od nich bowiem zależy, jaki kształt przyjmie w przyszłości myślenie o sprawach publicznych, czy pewne wartości i pewien sposób uprawiania polityki nie znikna na dobre ze świata, wreszcie czy Niemcy stana się „wielkim narodem”, który „[...] nie starzeje się pod ciężarem tysiącleci pełnej chwały historii. Pozostaje młody, jeśli zachowuje zdolność i odwage przyznania się do siebie i do wielkich instynktów, jakimi został obdarzony, jeśli jego warstwy przywódcze potrafią wznieść się ku sferom, gdzie w powietrzu ostrym i czystym [...] dojrzewaja owoce trzeźwej pracy polityki niemieckiej”20.

Przytoczony fragment jest istotny $z$ kilku względów. Po pierwsze, powraca $\mathrm{w}$ nim idea patriotyzmu jako wielkiej namiętności politycznej. Po drugie, znajdujemy tu odniesienie do „chłodnego oka”, rozwagi, jaka powinna cechować każdego polityka, w postaci sformułowania „trzeźwa praca polityki niemieckiej”. Po trzecie wreszcie, mamy tu wyraźne odwołania do Nietzschego, które pozwalaja dostrzec, jak dalece autor Tako rzecze Zarathustra ukształtował nie tylko idee polityczne Webera, ale także jego wyobraźnię. Sfera wielkiej polityki to wedle wielkiego socjologa miejsce, gdzie oddycha się „powietrzem ostrym i czystym”. Tymczasem Nietzsche powiada: „Kto umie oddychać powietrzem mych pism, ten wie, że jest to powietrze wyżyn, powietrze ostre. Trzeba być do niego stworzonym, bo inaczej niemałe będzie ryzyko przeziębienia się nim. Lód jest blisko, samotność jest ogromna - lecz jakże spokoj-

${ }^{19}$ Ibidem

20 Ibidem, s. 195. 
nie leżą rzeczy w świetle!"21. Wizja kogoś, kto zasiada na górskim szczycie i w rześkim powietrzu poranka przygląda się światu, ocenia sytuacje - to obraz, który pasuje równie dobrze do polityka $\mathrm{w}$ sensie, jaki stara się przekazać autor Gospodarki i społeczeństwa. Weberowskie "chłodne oko” jest okiem czytelnika nawykłego do oddychania powietrzem pism Nietzschego.

Powróćmy do głównego wątku naszych rozważań. Kwestia odpowiedzialności $\mathrm{w}$ polityce łączy się $\mathrm{u}$ Webera $z$ niezwykle istotnym i szeroko komentowanym rozróżnieniem na etykę przekonań (Gesinnungsethik) i etykę odpowiedzialności (Verantwortungsethik). Jak czytamy w szkicu Polityka jako zawód i powołanie: „[...] jest to niezmiernie głębokie przeciwieństwo: gdy $z$ jednej strony działa się według maksymy etyki przekonań, na przykład w myśl zasady religijnej, że "chrześcijanin czyni dobrze, a rezultat pozostawia Bogu", a $z$ drugiej strony - według maksymy etyki odpowiedzialności, ponoszac odpowiedzialność za (dające się przewidzieć) skutki swego działania"22. Etyka stawiajaca na pierwszym miejscu czystość przekonań, szlachetność intencji, jest bezradna wobec podziału na cele i prowadzące do nich środki. Bezradność ta bierze się ze swoistej krótkowzroczności, która każe winić za niepowodzenia otoczenie, świat, ludzką niedoskonałość. Jak pisze Weber: „[...] jeśli skutki działania płynącego $z$ czystych przekonań są złe, to dla niego [syndykalisty, którego autor przytacza jako przykład człowieka kierującego się etyką przekonań - przyp. P.M.] nie ten, kto działa, jest za to odpowiedzialny, lecz swiat, głupota innych ludzi lub wola Boga, który ich takimi stworzył"23. Etyka przekonań oznacza brak „chłodnego oka”, nieliczenie się z rzeczywistymi uwarunkowaniami politycznego działania. Tylko krok dzieli ją od prób urzeczywistnienia utopii - skoro ludzie sa niedoskonali lub głupi, należy ich poddać radykalnej przemianie lub starać się ostatecznie odmienić świat nieprzystający do naszych wyobrażeń. Stąd

\footnotetext{
${ }^{21}$ F. Nietzsche: Ecce Homo, przekład B. Baran, Wydawnictwo Baran i Suszczyński, Kraków 1995, s. 14.

${ }^{22}$ M. Weber: Polityka..., s. 102.

${ }^{23}$ Ibidem.
} 
wspominane przez Webera nawoływania do wszczęcia ostatecznej wojny, aby raz na zawsze skończyć $z$ wojnami, lub postulaty użycia przemocy po to, by miłość mogła ostatecznie zatryumfować. Etyka przekonań w skrajnej postaci ma jeden cel - wyeliminowanie ze świata wszelkiej różnorodności. Dotyczy to zarówno odmiennych wartości, za jakimi opowiadają się różni ludzie, jak i różnic w obrębie struktury społecznej czy odmiennych etosów zawodowych.

Robert Eden zwraca uwage na obecną w myśli Webera zależność między współczesnym podziałem pracy a Absolutethik, etyka oparta na twierdzeniach ważnych w każdych okolicznościach, powszechnie obowiazujacych nakazach moralnych ${ }^{24}$. Nadzorcę zastąpiło sumienie, w miejsce bata pojawił się wewnętrzny głos. Skoro praca jest obowiazkiem wobec Boga i własnego życia wiecznego, nie można jej zaniedbywać - zdaje się mówić ów cichy doradca. Życie zawodowe staje się powołaniem, nie można się od niego uchylać. Sa jednak ludzie, którzy mu się nie podporządkowują. Pojawia się napięcie będące źródłem polityki opartej na resentymencie, majacej zdyscyplinować niepokornych oraz utwierdzić posłusznych w ich przekonaniach, wzmocnić ich w wysiłkach i odsunąć od nich wątpliwości. Stąd już tylko krok w kierunku ujednolicajacych wszystko biurokratycznych procedur. Jak zauważa Robert Eden, autor słynnego szkicu o etyce protestanckiej i duchu kapitalizmu nie chciał dopuścić, aby świat pracy oraz szerzej - sfera publiczna podporzadkowały sie podobnym unifikujacym zasadom. Etyka odpowiedzialności jest sposobem na przezwyciężenie praktyk opartych na resentymencie i zachowanie zróżnicowania rozmaitych sfer ludzkiego życia.

W szkicu Polityka jako zawód i powołanie czytamy: „Etyka religijna rozmaicie radziła sobie $z$ faktem, że należymy do rozmaitych porządków życia, w których rządzą różne prawa. Helleński politeizm składał ofiary zarówno Afrodycie, jak Herze, zarówno Dionizosowi,

${ }^{24}$ R. Eden: Political Leadership and Nihilism. A Study of Weber and Nietzsche, University Presses of Florida, Tampa 1983, s. 199. 
jak Apollinowi, i wiedział, że nierzadko spierali się oni ze sobą. Hinduistyczny porządek życia czynił każdy z rozmaitych zawodów przedmiotem szczególnego prawa etycznego, dharmy [..."”25. Weber pokazuje tym samym, jak rozmaite religie radzily sobie $z$,irracjonalnością świata”; faktem, że wypełniaja go sprzeczne wartości. Nie poddaje się on jednej porzadkującej zasadzie, formułowanej przez wyznawców etyki przekonań. Ma to szczególne konsekwencje dla polityki. Jeśli zatryumfowałyby reguły postępowania oparte na absolutnych nakazach moralnych, nie byłoby w niej miejsca na patriotyzm, cnotę zasadniczą dla publicznego działania. Między patriotyzmem a wszelkimi uniwersalistycznymi projektami właściwego życia istnieje podstawowa sprzeczność. Nie da się pogodzić przekonania, że najlepszy dla danej wspólnoty sposób organizacji spraw publicznych to ten, który wyrósł, by użyć sformułowania Edmunda Burke'a, w „domowej perspektywie”, $z$ twierdzeniami głoszącymi, iż należy dążyć do obowiązującego powszechnie, bez względu na lokalne tradycje i specyficzne uwarunkowania historyczne, modus vivendi.

Problem ten można postawić nieco inaczej i ukazać go jako sprzeczność między dażeniem do zbawienia duszy a troską o własną zbiorowość polityczną. O ile warunki zbawienia sformułowane sa w kategoriach etyki przekonań i jako takie sa jednakowo obowiąujące dla wszystkich, o tyle chcąc ocalić swój kraj w obliczu napaści, musimy się przeciwstawić naukom zawartym choćby w Kazaniu na Górze. Takiego właśnie wyboru dokonuja przywoływani w szkicu Polityka jako zawód i powołanie obywatele Florencji, których Machiavelli chwali ustami jednego ze swoich bohaterów za to, że „wielkość ojczystego miasta była dla nich droższa niż zbawienie duszy"26. Weber opisuje tę niemożliwą do pogodzenia sprzeczność następującymi słowami: „Geniusz czy demon polityki żyje $z$ bogiem miłości, także $z$ Bogiem chrześcijańskim $w$ jego kościelnej postaci, w wewnętrznym napięciu, które w każdej chwili

${ }^{25}$ M. Weber: Polityka..., s. 104.

${ }^{26}$ Ibidem, s. 108. 
może eksplodować jako konflikt nie do rozstrzygnięcia” ${ }^{27}$. Można zatem uznać, że odpowiedzialne działanie polityczne wymaga także zdania sobie sprawy $z$ faktu, iż angażując się $\mathrm{w}$ politykę, stawiamy na szali własne zbawienie.

Nie oznacza to jednak, że Weber nie przyznaje etyce przekonań żadnego miejsca w duszy polityka. Łączy ja $z$ „rzeczowościa”, rozumiana jako "namiętne oddanie sprawie” i przeciwstawiona ,jałowemu podnieceniu". Probierzem jest tu "wewnętrzna powaga" stojacca za głoszonymi poglądami. Jak czytamy w szkicu Polityka jako zawód i powołanie: „[...] jest rzecza ogromnie wstrzasająca, jeśli człowiek dojrzały [...] który odpowiedzialność za skutki odczuwa realnie i cała duszą i działa według etyki odpowiedzialności, powie w którymś momencie: "Przy tym stoje i nie moge inaczej"”28. Moment podejmowania decyzji, kiedy polityk zdaje sobie sprawę $z$ konsekwencji czynionego wyboru, a jednak decyduje się być wiernym sprawie uznanej niegdyś za własną, to dla Webera samo jadro polityki, niejako polityka w stanie czystym. Jest on przy tym przekonany, że „każdy $z$ nas, kto nie jest wewnętrznie martwy, kiedyś będzie zapewne mógł poznać ten stan" ${ }^{29}$.

Powracamy tu zatem do nietzscheańskiego wątku polityki rozumianej jako narzędzie osiagania przez człowieka pełni jego egzystencji. Aby nie być „wewnętrznie martwym”, należy zaangażować się w sprawy publiczne. Sa one siedliskiem tragicznych sprzeczności, których doświadczanie stanowi o pełni człowieczeństwa. Nie można jej osiagnąć chowając się w „zaciszu starych kościołów". Stajemy się prawdziwie ludźmi dopiero wówczas, gdy dokonujemy wyborów i bronimy własnych decyzji, to zaś często wiąże się $z$ użyciem przemocy: „Kto chce uprawiać politykę w ogóle lub nawet traktować ja jako zawód, musi być świadom tych etycznych paradoksów i swojej odpowiedzialności za to, co może stać się $z$ nim samym pod ich ciśnieniem. Zadaje się on, powtarzam to,

\footnotetext{
${ }^{27}$ Ibidem, s. 107

${ }^{28}$ Ibidem, s. 109

${ }^{29}$ Ibidem.
} 
z diabelskimi mocami, które kryją się za każda przemocą", czytamy w eseju Polityka jako zawód i powołanie ${ }^{30}$. Przemoc zatem, jak powiada Weber, zmienia nie tylko świat, ale także człowieka nadającego światu kształt. W polityce definiujemy się poprzez dokonywane wybory. Jeśli pozwolimy, aby przemoc stała się dla nas wartościa sama $\mathrm{w}$ sobie lub środkiem osiagnięcia korzyści materialnych, stawiamy na szali, jak to już zostało powiedziane, nie tylko własne dusze, lecz również ideały, których obiecywaliśmy bronić rozpoczynając karierę publiczną. Użycie przemocy wiąże się zatem ze szczególnego rodzaju odpowiedzialnościa, jaka powinna cechować każdego polityka - odpowiedzialnością za samego siebie.

\section{Polityka i przemoc}

Dlaczego polityka nierozerwalnie wiąże się z przemocą? Jakie przyczyny każą Weberowi twierdzić, że każdy polityk godzi się na stosowanie „środków prawomocnej przemocy”, przy czym owa prawomocność jest często wysoce watpliwa w momencie podejmowania decyzji o ich zastosowaniu? Wydaje się, że odpowiedź zwiazana jest $z$ kwestia zmiany społecznej, $z$ problemem innowacji w życiu zbiorowym.

Stephen Turner i Regis Factor, autorzy interesujacej pracy Max Weber: The Lawyer as Social Thinker, porównuja poglady autora Gospodarki i społeczeństwa z pracami współczesnych Weberowi znamienitych filozofów prawa, wskazując na rozmaite paralele i różnice ${ }^{31}$. Interesujacy mnie $\mathrm{w}$ tym momencie fragment dotyczy związków myśli wielkiego socjologa $z$ koncepcjami jednego $z$ czołowych niemieckich jurystów drugiej połowy XIX wieku, Rudolfa von Iheringa. Jednym $z$ zasadniczych zagadnień była dla niego kwe-

\footnotetext{
${ }^{30}$ Ibidem, s. 107

${ }^{31}$ S. Turner, R. Factor: Max Weber: The Lawyer as Social Thinker, Routledge, London - New York 1994.
} 
stia relacji między prawem a przemoca. Przemoc pochodzi spoza porzadku prawnego, a jednak zmiany wprowadzone za jej pomoca często staja sie prawem. Ten proces czynienia prawomocnym tego, co uprzednio było nieprawomocne - i to przy użyciu środków, którym również brakuje prawomocności - był dla Iheringa punktem wyjścia do namysłu nad mechanizmami zmiany społecznej odzwierciedlonej w przeobrażeniach porządku prawnego. Brutalna siła stanowi tego porządku podstawę, bez niej nie mógłby on zaistnieć i utrzymać się. Co więcej, ludzie w tym wczesnym stadium rozwoju prawodawstwa postrzegaja przemoc jako prawomocny środek zaprowadzania spokoju. Jak pisze Ihering: „instynktownie rozumieja, że potrzeba rządów twardej ręki w niespokojnych czasach, by zmusić niepokornych do podporządkowania się wspólnemu działaniu, że potrzeba lwa, aby poskromił wilki, nie czyniąc przy tym szkody owcom"32. Na tym jednak nie koniec, przemoc nie jest obecna jedynie przy owym „akcie założycielskim”, by użyć terminu stosowanego przez Machiavellego. Dla Iheringa prawo spełnia rolę służebna, jest środkiem mającym zapewnić trwanie społeczeństwa. W sytuacji, w której istniejacy porządek prawny nie odpowiada potrzebom społecznym, pojawia się konieczność ponownego zastosowania siły. W momencie, gdy trzeba wybierać „między prawem a życiem, decyzja jest prosta: należy poświęcić prawo i ocalić życie. Na tym polegaja zbawienne czyny rządu" ${ }^{33}$. Zastosowanie drastycznych środków poczatkowo wywołuje protesty ze strony obrońców starego porzadku, stopniowo jednak ich głosy cichną, by stać się zupełnie niesłyszalne - nowy porządek zostaje uprawomocniony. Dlaczego tak się dzieje? Dla Iheringa wprowadzanie prawa siła, dokonywanie w nim zmian radykalnymi metodami, na przykład podczas rewolucji czy zamachu stanu, stanowi próbę włączenia do legalnego porzadku nowych interesów, do tej pory nieuwzględnianych lub uwzględnianych $\mathrm{w}$ niedostatecznym stopniu.

\footnotetext{
${ }^{32}$ R. Ihering: Law as a Means to an End, cyt. za: S. Turner, R. Factor: Max Weber: The Lawyer..., s. 106.

${ }_{33}$ Ibidem, s. 107.
} 
Weber nie przystaje na automatyzm, $z$ jakim $w$ powyższej propozycji przemoc podlega legitymizacji. Inaczej widzi sytuację wyjściowa - nie ma u niego miejsca na „instynktowna potrzebe przemocy" majacej zapewnić porządek i bezpieczeństwo. Przemoc jest faktem, jej stosowanie jest naturalne i nie jest w żaden sposób ograniczone. $Z$ jednej strony Weberowska wizja jest o wiele bardziej brutalna, przemoc nie podlega tu bowiem normom, wobec których miałaby być służebna, chyba że za normę uznamy klanowe prawo do zemsty. W Gospodarce $i$ społeczeństwie czytamy: „Jeśli przedstawienie swoistej prawomocności odwołującego się do przemocy działania wiąże się $z$ jakimkolwiek zgodnym działaniem, to $z$ działaniem rodu w przypadku spełniania obowiazku krwawej zemsty"34. Z drugiej jednak strony takie postawienie problemu oznacza wyłączenie ludzi spod mocy działania wszelkiej dziejowej konieczności oraz przyznanie im prawa do swobodnego decydowania o sobie. W uformowanej dobrowolnie i nieco przypadkowo grupie wojowników - a więc w sytuacji poprzedzajaccej, wedle Webera, powstanie bardziej zaawansowanych form działania politycznego - przywódca jest obierany w sposób wolny, ze względu na swe indywidualne zalety: charyzmę. To charyzma staje sie podstawowym narzędziem legitymizacji i pozwala na uniknięcie automatyzmu wiażącego nierozerwalnie prawomocność wszelkich zmian z przemoca: „Zawierzenie charyzmie proroka lub wodza wojennego albo rzeczywiście wielkiego demagoga w eklezji czy w parlamencie oznacza, że uznaje się go osobiście za wewnętrznie "powołanego" kierownika ludzi, że podporządkowuja mu się oni nie na mocy obyczaju czy ustanowienia, lecz dlatego, że w niego wierza", pisze autor Gospodarki i społeczeństwa ${ }^{35}$. Zmiana społeczna nie rodzi się zatem $z$ brutalnej siły, lecz $z$ charyzmatycznego „objawienia”. Żaden przywódca jednak, nawet jeśli jest politykiem $z$ powołania, jak powiada Weber za Nietzschem - wiernym swoim ideałom

\footnotetext{
${ }^{34}$ M. Weber: Gospodarka $i$ społeczeństwo, przekład D. Lachowska, Wydawnictwo Naukowe PWN, Warszawa 2002, s. 653.

${ }^{35}$ Ibidem, s. 1024.
} 
i „chcącym urzeczywistnić dzieło”, nie może sprawować władzy bez aparatu administracyjnego, to zaś naraża go na niebezpieczeństwa zwiazane ze stosowaniem przemocy.

Weber krytykuje myślenie utopijne w polityce i koncentrowanie się w działaniu publicznym jedynie na czystości intencji, które stoja za owym działaniem, przy jednoczesnym ignorowaniu jego dajacych się przewidzieć skutków. Utopista nieuchronnie traci kontakt $z$ rzeczywistościa, nie zdaje lub nie chce sobie zdawać sprawy $z$ tego, iż ludzie nie sa aniołami, rzeczywistość zaś nie zawsze przystaje do jego, choćby nawet najbardziej szlachetnych, zamysłów. Dlatego też konieczność kierowania grupa zwolenników w celu urzeczywistnienia jakiegoś projektu wiąże się dla niego ze szczególnymi zagrożeniami. W szkicu Polityka jako zawód i powołanie pisze: „Kto chce przemoca zaprowadzić na ziemi absolutną sprawiedliwość, potrzebuje do tego stronników: "aparatu ludzkiego»"36. Aby pociagnąc za soba ludzi, owładnięty utopijnymi pomysłami wizjoner musi im obiecać „wewnętrzne i zewnętrzne nagrody”.

Podział ten jest interesujacy, nie pokrywa się bowiem $z$ rozróżnieniem na nagrody wieczne i doczesne. Wewnętrzne beneficja - to utwierdzenie w słuszności własnych poglądów i uczuć, które w sytuacji „nowoczesnej walki klasowej” przyjmuja zazwyczaj formę resentymentów. Jeśli zestawimy to $z$ wcześniej przytoczonymi twierdzeniami odnośnie do nowoczesnego podziału pracy i resentymentu zrodzonego zeń na podłożu etyki absolutnej, dostrzeżemy, jak bardzo propozycja Webera odbiega od poglądów Rudolfa von Iheringa na przemoc jako innowacyjna siłe czy rewolucję rozumiana jedynie jako narzędzie zmiany istniejacego status quo. Brutalna siła może być użyta do podtrzymania istniejącego ładu, a rewolucjoniści i wizjonerzy moga równie dobrze bronić istniejącego porządku za wszelką cenę. Jak zwracał uwagę Robert Eden, w nowożytnym społeczeństwie przemysłowym istnieje konflikt między tymi, którzy poświęcają się pracy traktując ją jako „powoła-

\footnotetext{
${ }^{36}$ M. Weber: Polityka..., s. 106.
} 
nie", a tymi, dla których nie ma ona uświęconego charakteru. Pracownicy słuchający głosu sumienia traktuja pozostałych jako niemoralnych; są oni dla nich grzesznikami, należy ich niezwłocznie nawrócić. Tym samym etyka przekonań, mająca wszelkie dane po temu, by stać się podstawa dla rewolucji mającej naprawić swiat, ujednolicić go tak, aby pasował do określonych poglądów, paradoksalnie staje na straży kapitalistycznego ładu będącego owych poglądów pochodna.

Tak rozumiane wewnętrzne korzyści maja, podobnie jak nagrody zewnętrzne (jak pisze Weber: „zwycięstwo, łup, władza”), charakter doczesny, ziemski, by nie rzec przyziemny, i jako takie zazwyczaj stoją $\mathrm{w}$ sprzeczności $\mathrm{z}$ absolutnymi ideałami przyświecającymi przywódcy. Podstawowe zagrożenie polega na tym, że nie zdaje on sobie sprawy $z$ tego rozdźwięku zakładajac, że personel podziela jego wiarę. Gdy jednak dostrzeże swoja pomyłkę, pojawia się zniechęcenie. W szkicu Polityka jako zawód i powołanie czytamy: „[...] po emocjonalnej rewolucji przychodzi tradycjonalistyczna codzienność, bohater wiary, a przede wszystkim sama wiara, znika lub też staje się [...] przedmiotem konwencjonalnej, czczej gadaniny politycznych kołtunów i techników”37. „Bohater wiary” staje się zakładnikiem swoich podwładnych, podobnie jak tyran w Państwie był pierwszym więźniem we własnych włościach, uzależnionym od swojej gwardii, dla której był gwarantem zaspokajania rozmaitych interesów. W gruncie rzeczy bardzo wiele łączy postać tyrana tak, jak przedstawiali ja starożytni greccy myśliciele polityczni, $z$ weberowskimi rewolucjonistami chcacymi przekształcić świat zgodnie ze swymi ideałami. Więcej powiem o tym w podrozdziale Weberowski polityk a kategorie tyranii i totalitaryzmu.

W przeciwieństwie do utopijnie myślącego lidera rewolucji moralnej, polityk obdarzony „chłodnym okiem” doskonale zdaje sobie sprawę $z$ dwóch faktów. Po pierwsze, wie, że powodzenie jego działań zależy w dużej mierze od aparatu państwowego, którym zmu-

37 Ibidem, s. 107. 
szony jest się posługiwać przy realizacji swoich zamysłów. Po drugie, jest świadom wielości czasem sprzecznych interesów, jakie przyświecaja jego podwładnym. Nie ma złudzeń, że podzielaja oni jego namiętności. Nie oczekuje od nich wierności jego „demonowi”, wybranym niegdyś przez niego wartościom: „[...] politycy $z$ "powołania", w najściślejszym sensie tego słowa, nie sa jednak nigdzie jedynymi miarodajnymi figurami w wirze politycznej walki o władzę. Rozstrzygajacy jest raczej rodzaj środków pomocniczych, jakimi rozporzadzaja", pisze Weber w Gospodarce $i$ społeczeństwie ${ }^{38}$. Polityk potrafiacy zdobyć się na dystans do otaczajacej go rzeczywistości jest świadom tych uwarunkowań swojego działania. Wie, że „wiercenie w twardych deskach" oznacza także $z$ jednej strony konieczność wyegzekwowania subordynacji od swoich podwładnych, $z$ drugiej zaś wiąże się ze stosowaniem przemocy fizycznej, co byłoby niemożliwe bez personelu administracyjnego.

\section{Weberowski polityk a kategorie tyranii i totalitaryzmu}

Nie ulega wattpliwości, że największym wyzwaniem, jakie stanęło w XX wieku przed filozofia polityki było powstanie reżimów określonych $z$ czasem mianem totalitarnych. Większość myślicieli politycznych stanęła bezradna wobec ponurego zjawiska, o którym myślenie przychodziło $z$ najwyższym trudem wobec niedostatków wiarygodnych informacji i braku narzędzi analitycznych. Niektórzy filozofowie ulegli i dali się porwać maszerującym kolumnom. Nieliczni podjęli próbę refleksji nad przerażającym fenomenem. Najsłynniejszym efektem tych prób sa Korzenie totalitaryzmu Hannah Arendt ${ }^{39}$. W pracy tej Arendt wskazuje na całkowicie nowy charakter władzy totalitarnej, jej absolutna płynność i brak pod-

\footnotetext{
${ }^{38}$ M. Weber: Gospodarka..., s. 1025

${ }^{39}$ H. Arendt: Korzenie totalitaryzmu, przekład M. Szawiel, D. Grinberg, Niezależna Oficyna Wydawnicza, Warszawa 1993.
} 
stawy społecznej. Panowanie totalitarne nie służy żadnemu celowi, jego jedynym celem jest ono samo. Despota i tyran zaspokajali własna próżność, żądzę bogactwa, chęć wymuszenia na innych posłuszeństwa. W państwie totalitarnym nikt, łącznie $z$ najwyższymi przywódcami partyjnymi, nie może być bezpieczny. Nie sposób przewidzieć, przeciw komu zostanie skierowana kolejna fala represji. Nie sposób też owych represji uniknąć poprzez określone zachowanie czy unikanie jakiegoś rodzaju postępowania. Władza totalitarna jest ślepa i znajduje się w ciagłym ruchu. Inny opis totalitaryzmu dał Franz Neumann, niemiecki Żyd, któremu udało się uciec $z$ nazistowskich Niemiec, w wydanej po raz pierwszy w 1942 roku w Stanach Zjednoczonych pracy Behemoth ${ }^{40}$. Neumann stosuje w swojej analizie narzędzia zaczerpnięte $z$ marksizmu, wskazując na porozumienie między wielkim kapitałem a narodowymi socjalistami, na zmiany wprowadzone przez nowych władców na niemieckiej wsi i w wielkich zakładach przemysłowych, na gromadzenie w jednych rękach coraz większego kapitału, czy to pod postacią stale powiększanych majątków ziemskich, czy to dzięki wielkim rządowym zamówieniom. Wedle Neumanna państwo totalitarne to ociężała bestia, która stale rośnie i bogaci się kosztem społeczeństwa. Sa jednak w książce fragmenty, w których autor porzuca schematy klasowe i wykrzykuje przerażony, relacjonując na przykład zmiany w prawie dokonane przez nazistów, iż mogli ich dokonać jedynie „zupełni poganie”.

Arendt starała się pokazać, że tradycyjna klasyfikacja ustrojów nie ma żadnego zastosowania przy analizie totalitaryzmu. Neumann starał się opisać państwo totalne używając kategorii wypracowanych przez marksizm w dobie uprzemysłowienia - $\mathrm{i}$ język ten okazał się w wielu miejscach niewystarczajacy. Do jakiego stopnia zatem jest totalitaryzm fenomenem związanym $z$ nowoczesnością? Czy do jego opisu potrzeba nowego języka, czy też trudności związane sa $z$ tym, że zapomnieliśmy o pewnych kategoriach wypraco${ }^{40}$ F. Neumann: Behemoth. The Structure and Practice of National Socialism 1933-1944, Octa-
gon Books, New York 1963. 
wanych przez klasyczna myśl polityczna, jak na przykład kategoria ustroju tyrańskiego? Wyczerpująca odpowiedź na te pytania wykracza poza ramy niniejszego tekstu, postaram się jednak rzucić na te kwestie nieco światła rozważajac, w jakim stopniu polityka w kształcie, jaki proponuje Max Weber, jest zabezpieczona przed niebezpieczeństwami tyranii i totalitaryzmu.

Mark Lilla w eseju Nowy wiek tyranii stawia tezę, że problemy, jakie miała filozofia polityki $z$ opisaniem i zrozumieniem totalitaryzmu były spowodowane odejściem od pojęcia tyranii w znaczeniu, jakie nadała mu $\mathrm{w} \mathrm{V}$ wieku p.n.e. klasyczna grecka myśl polityczna ${ }^{41}$. Sokrates Platona i Ksenofonta określa tyranię jako "zepsuta formę rządów”, ponieważ odchodzi ona od duchowego ładu jako podstawy dobrego państwa. Złe rzady sa odzwierciedleniem nieporzadku panujacego $\mathrm{w}$ duszach obywateli. Arystoteles pokazuje, że podobny nieporządek może się zrodzić zarówno w sytuacji jedynowładztwa, jak i w oligarchiach czy demokracjach. Niekoniecznie musi być efektem panowania ogarniętej żądzą władzy i chorobliwą ambicja jednostki, ale również zepsucia instytucji publicznych i obyczajów całej wspólnoty. Nowoczesność odeszła od tych poczynionych w Atenach odkryć, od czasu Rewolucji Francuskiej tyrania przestaje być problemem politycznym. Jak pisze Lilla: „wielcy XIX-wieczni twórcy systemów wszędzie odnajdywali tyranię - wszędzie, tylko nie na powierzchni życia politycznego" ${ }^{\text {"2 }}$. $\mathrm{Za}$ ostatnich reprezentantów tej zrodzonej w XIX wieku refleksji uznaje Freuda i Webera: „Freud chcial pomóc nowoczesnym jednostkom w zrzuceniu tyranii przeszłości, która ich nieświadomie więziła. Weber zaś pragnął oswoić ich z życiem w "żelaznej klatce» zracjonalizowanego, biurokratycznego świata, który stał się całkowicie "odczarowany". Obaj zeszli $z$ tego świata, nie będąc w stanie wyjaśnić odrodzenia politycznej tyranii w XX wieku. Wiele mówiący jest fakt, że w dwóch opasłych tomach Gospodarki i społeczeństwa [...] problemowi tyrana poświęcono tylko dwie strony, na których

\footnotetext{
${ }^{41}$ M. Lilla: Nowy wiek tyranii, przekład M. Warchala, „Europa - Tygodnik Idei” 2005, nr 61.

42 Ibidem, s. 6.
} 
traktuje się go wyłącznie jako starożytną formę "władzy nieprawomocnej" "43.

Czy rzeczywiście Weber nie dostrzegł zagrożenia polityczna tyranią, która wkrótce miała wziąc we władanie Niemcy? Wydaje się, że rację ma Pierre Manent, kiedy pisze: „Weber dobrze rozumiał, że rozdział pomiędzy życiem i nauką okaże się nie do zniesienia dla przeciętnego człowieka. Słusznie zauważył przy tym, że ten stan rzeczy spowoduje powstanie oszukańczego monumentalizmu, fałszywego profetyzmu i pedantycznego fanatyzmu"44. W szkicu $\mathrm{Na}^{\mathrm{M}}$ uka jako zawód i powołanie Weber wskazywał na podział między faktami a wartościami, który staje się zasadniczym rysem nowoczesności. Nauka, jeśli chce być uczciwa wobec samej siebie, może wyrokować jedynie o tych pierwszych, nie może jednak wskazać sensu życia; dowieść, że jedna $z$ wielu sprzecznych wartości jest bardziej prawdziwa, szlachetna czy piękna od pozostałych. Konieczność dokonywania wyborów i nieustannego ich potwierdzania okazuje się dla niektórych ludzi zadaniem ponad siły, stąd „pogoń za przeżyciem" oraz próba tworzenia nowych bogów, nowych uniwersalnych zasad mogacych posłużyć w życiu za drogowskazy. Podobne próby okazują się mieć zgubne skutki: „Kiedy zaś próbujemy wymyślać nowe, pozbawione prawdziwego ducha proroczego religie, wtedy powstaje coś $\mathrm{w}$ najgłębszym sensie podobnego do owych dzieł [tj. dzieł sztucznie stworzonej sztuki monumentalnej, które Weber uznaje za „żałosne dziwolagi” - przyp. P.M.], tyle że majacego jeszcze gorsze skutki”"45. Lekarstwem na stan rezygnacji, mogący łatwo pchnać szerokie rzesze ludzi w objęcia fałszywych proroków i fanatyków, staje się, wedle Webera, znalezienie „własnego demona”, wartości, która okaże się dla jednostki celem życiowych dążeń. Każdy jednak musi dokonać owego wyboru sam, na tym polega zasadnicza powinność spoczywająca

\footnotetext{
${ }^{43}$ Ibidem, s. 6.

${ }^{44}$ P. Manent: Powrót filozofii..., s. 35.

${ }^{45}$ M. Weber: Nauka..., s. 139.
} 
na barkach nie tylko polityków, ale także wszystkich obywateli. Odpowiedzialność okazuje się zatem obroną przed tyranią.

W artykule $W$ sprawie „winy za wojne" Weber daje nieco inny dowód tego, iż był świadom śmiertelnego zagrożenia, jakie wisiało nad Niemcami. Czytamy tam: „Powiedzmy tylko tyle: oddanie Saarbrucken, Botzen, Rechenberga [Liberca], Gdańska i innych miast $\mathrm{w}$ ręce obcych narodów, pozbawienie nas [...] prawa rozporządzania niemieckimi rzekami i kanałami, pańszczyźniana niewola i branie zastawu za roszczenia wynikłe ze szkód, które są wyłącznie skutkami wojny - wszystko to sprawiłoby oczywiście, że również najbardziej radykalny politycznie robotnik niemiecki - nie teraz, ale zapewne po jakimś czasie, kiedy minie już obecne odurzenie i postępujące za nim osłabienie - stałby się szowinistą i że wspólnie $z$ intelektualnymi warstwami narodu musiałby przypomnieć sobie o tych rewolucyjnych środkach samostanowienia, którymi posługiwała się każda irredenta [...]"46. Odmowa przyjęcia odpowiedzialności za ustanowienie powojennego ładu przez zwycięzców oraz wynikajace $z$ tego narastanie $u$ pokonanych resentymentu, który znajduje ujście w wybuchu narodowego szowinizmu - podobna ocena sytuacji okazuje się mieć postać niemal proroctwa. Brak trzeźwej oceny sytuacji po obu stronach, wygranej i przegranej, może prowadzić do tragicznych konsekwencji. Weber nie dożył już ponurej chwili, kiedy spełnił się ów najgorszy przepowiedziany przez niego wariant wydarzeń.

Inny, o wiele poważniejszy zarzut podnoszony wobec Webera głosi, iż proponowana przez niego wizja polityki nie tyle nie bierze pod uwage zagrożenia tyrania czy totalitaryzmem, ile zawiera dla nich przyzwolenie. Jako przykład tego rodzaju krytyki jest przywoływany przez Johna Patricka Digginsa w pracy Max Weber. Politics and the Spirit of Tragedy artykuł Meyera Schapiro, opublikowany w 1945 roku w mocno lewicowym piśmie Politics ${ }^{47}$. Schapiro uwa-

\footnotetext{
${ }^{46}$ M. Weber: W sprawie „winy za wojne”, w: idem: Polityka..., s. 247.

${ }^{47}$ Por. J.P. Diggins: Max Weber. Politics and the Spirit of Tragedy, Basic Books, New York 1996, s. 270 .
} 
ża, że pokładając nadzieję na odnowę życia politycznego w charyzmatycznym przywódcy, krytykując biurokratyczny legalizm oraz przedstawiajac masy jako irracjonalne i niezdolne do samostanowienia, Weber opowiadał się pośrednio za polityka siły, która utorowała droge do władzy Hitlerowi. Wielkiego socjologa broniono przed podobnymi zarzutami, wskazujac na jego osobiste przymioty, dumę i cywilną odwagę w konkretnych sytuacjach, jak choćby wstawienie się za uwięzionym $z$ przyczyn politycznych socjalista Ernstem Tollerem. Czynili tak na przykład Karl Jaspers, Wolfgang Mommsen czy polemista Schapira, Hans Gerth. Tezy Schapira stoja jednak przede wszystkim w sprzeczności $z$ propozycjami teoretycznymi Webera. Po pierwsze, zalecał on, co zostało pokazane w części Przemoc $w$ polityce, bardzo ostrożne używanie siły, uważał ja bowiem za „diabelska moc”, choć uznawał konieczność stosowania jej w sferze publicznej. Po drugie, mimo iż rzeczywiście obawiał się, że masy moga nazbyt często kierować się resentymentem czy ,jałowym podnieceniem”, to wierzył w zdolność poszczególnych jednostek do samodzielnego decydowania o sobie. Przerażała go wizja społeczeństwa zamienionego w "stado owiec”, jak napisał o Rosji bolszewickiej. Po trzecie wreszcie, zaciekle bronił prawa do dokonywania wyboru między rozmaitymi wartościami i obawiał się fanatyków, chcacych odebrać ludziom możliwość wybierania między różnymi celami życiowymi i narzucić im jedną, powszechnie obowiąujaca „prawdę”. Brutalna siła nigdy nie mogła zastapić charyzmy w roli czynnika legitymizującego władzę, charyzma zaś opierała się dla niego przede wszystkim na dobrowolnym uznaniu.

O ile wypada odrzucić tezę o tym, że Max Weber nie dostrzegł zagrożenia tyrania oraz pogląd głoszący, iż jego nauka zawiera przyzwolenie dla totalitaryzmu, o tyle pozostaje kwestia problematyczna, czy jego wizja polityki stanowiła propozycję będaca mocna i realistyczna alternatywa wobec nadciagajacego politycznego kataklizmu. Wielki socjolog mógł słusznie rozpoznawać zagrożenia i starać się im przeciwdziałać, łącząc w swojej propozycji teoretycznej polityke oparta na wielkich wizjach $z$ ladem liberalnych 
procedur, a jednak jego projekt okazał się nieskuteczny. Dlaczego tak się stało? Być może problem leży głębiej. Być może porażka Webera była spowodowana nie tyle jego krótkowzrocznościa, ile przyjęciem błędnej perspektywy, która kazała mu najpoważniejsze obawy wiązać $z$ ludźmi nie potrafiącymi mężnie znieść przyniesionego przez nowoczesność podziału na „fakty” i „wartości”, zamiast zakwestionować zasadność owego podziału. W tym właśnie będzie widział największy błąd „szlachetnego nihilisty” Leo Strauss. 